\title{
RELATIONSHIP BETWEEN THE AGE OF HUMAN ERYTHROCYTES AND THEIR OSMOTIC RESISTANCE: A BASIS FOR SEPA- RATING YOUNG AND OLD ERYTHROCYTES ${ }^{1,2}$
}

\author{
By PAUL A. MARKS ANd ANNE B. JOHNSON \\ (From the Department of Medicine, Columbia University, College of Physicians and Surgeons, \\ and the Medical Services of the Francis Delafield Hospital and the Presbyterian \\ Hospital, New York, N.Y.)
}

(Submitted for publication June 19, 1958; accepted July 24, 1958)

A study has been made of the effect of age on the susceptibility of mature human erythrocytes to hemolysis in hypotonic media. The alterations in osmotic fragility associated with red cell aging are pertinent to the relationship between cellular senescence and the maintenance of cell mambrane integrity. In addition, differences in osmotic resistance between young and old erythrocytes could provide a basis for separating the whole red cell population into fractions of differing mean cell age. A method for achieving such a separation would permit investigation of biochemical changes associated with in vivo aging of erythrocytes.

On the basis of experiments with red cells of dogs, Cruz, Hahn, Bale and Balfour (2) and Stewart, Stewart, Izzo and Young (3) concluded that young canine erythrocytes were less resistant to hypotonic lysis than older cells. Recent evidence suggests that the young erythrocytes of rabbit (4, 5), rat and (6) and man (7) are more resistant to hemolysis in hypotonic media than are older cells.

In the present investigation, $\mathrm{Fe}^{59}$ has been employed to label, in vivo, erythrocytes of a limited age $(8-11)$. It has been found that graded osmotic hemolysis may achieve a separation of red cells into fractions of relatively young and old mean cell ages. The young human erythrocytes are more resistant to hemolysis in hypotonic media than older cells.

\section{METHODS}

The subjects studied included four persons in good health (Subjects LO, LA, DE and LI) and four patients with neoplastic disease. Among these patients, one had carcinoma of the breast (Subject W), two had car-

1 A portion of the present data was presented before the Society for Clinical Investigation, Atlantic City, New Jersey, May, 1957, and appeared in abstract form (1).

2 This work was supported in part by Grant C2332 of the National Cancer Institute. cinoma of the lung (Subjects $Z$ and $T E$ ) and one had osteosarcoma (PR). The ages of these subjects ranged between 23 and 64 years and four of them were females (Subjects W, LA, LO and LI). During the entire course of study, all subjects had normal values for hemoglobin, red blood cell count, hematocrit and reticulocyte count.

Ten to $30 \mu \mathrm{c}$. of $\mathrm{Fe}^{\mathrm{s0}}$ iron globulin complex were administered intravenously to each person. At intervals up to 120 days following isotope administration, 15 to 30 $\mathrm{ml}$. of heparinized venous blood were drawn for fractionation of the erythrocytes by graded osmotic hemolysis. Beginning 14 days after $\mathrm{Fe}^{50}$ iron administration, all subjects were given $1.2 \mathrm{Gm}$. of ferrous sulfate per day for the duration of the study.

Fractionation of erythrocytes by graded osmotic hemolysis. All blood samples were centrifuged at $1,500 \times$ $\mathrm{G}$ for 10 minutes and the plasma and buffy coat removed by aspiration. The erythrocytes were washed twice with a solution of isotonic potassium chloride adjusted to $\mathrm{pH}$ 7.4 by addition of potassium bicarbonate and resuspended in this solution so as to provide a hematocrit of approximately 80 per cent. This procedure and all ensuing steps in the graded osmotic hemolysis were performed at $0^{\circ} \mathrm{C}$. The resuspended washed erythrocytes were contaminated by fewer than 0.05 per cent leukocytes and 0.5 per cent reticulocytes.

One $\mathrm{ml}$. aliquots of the resuspended washed erythrocytes were added to a series of tubes containing $5 \mathrm{ml}$. of solutions of varying concentrations of sodium chloride (usually 0.30 to 0.46 per cent sodium chloride) and a tube containing $5 \mathrm{ml}$. of distilled water. The tubes were mixed by inverting five times and allowed to stand at $0^{\circ} \mathrm{C}$. for 10 minutes. The samples were centrifuged at $1,500 \times \mathrm{G}$ for 10 minutes and supernatant solutions removed. The sedimented unlysed erythrocytes were washed promptly with 10 volumes of the ice cold isotonic potassium chloride buffered at $\mathrm{pH} 7.4$ and resuspended in approximately $2 \mathrm{ml}$. of this solution.

The concentrations of the sodium chloride solutions employed were empirically chosen to cause hemolysis of 2 plus or minus $0.5,5$ plus or minus 1,10 plus or minus 1,90 plus or minus 1,95 plus or minus 1 and 98 plus or minus 0.5 per cent of the added erythrocytes. The extent of hemolysis in the water tube was taken as equal to 100 per cent. The per cent hemolysis achieved by a given concentration of sodium chloride was taken as 
equal to the ratio of the hemoglobin concentration in its supernatant solution to that of the solution of water-lysed erythrocytes multiplied by 100 .

Determination of $F e^{s 0}$ specific activity of hemoglobin. Hemoglobin was partially purified from the resuspended whole erythrocyte population, the water-lysed cells and the supernatant solutions and sedimented erythrocytes of the various sodium chloride tubes by a modification of the method of Drabkin (12). To one volume of each hemolysate, one-half volume of toluene was added and the mixture was thoroughly shaken until a fine emulsion was formed. After standing at $4^{\circ} \mathrm{C}$. for two hours the solutions were centrifuged for 20 minutes at $4,000 \times G$ and the water layer was removed. This "hemoglobin solution" was centrifuged at $18,000 \times \mathrm{G}$ for 60 minutes. A $2 \mathrm{ml}$. aliquot of the resultant clear supernatant "hemoglobin solution" was then assayed for radioactivity in a well type scintillation counter. The specific activity of these "hemoglobin solutions" was expressed as counts per minute per $\mathrm{Gm}$. of hemoglobin. The relative specific activities of the "hemoglobin solutions" did not differ significantly from that of heme crystallized from these solutions (13). Hemoglobin concentrations were measured by pipetting a suitable quantity of the solution into a 3 ml. cuvette, making it up to a total volume of $2.5 \mathrm{ml}$. with 0.4 per cent ammonium hydroxide. The optical density of the solutions was determined in a spectrophotometer at $540 \mathrm{~m} \mu$. Duplicate hemoglobin determinations did not differ by more than plus or minus 2.0 per cent. The standard error of the counting procedure was less than plus or minus 2 per cent for most samples and less than plus or minus 5 per cent for the low activity specimens.

Iron 59 labeled hemoglobin recovery studies. It was necessary to determine whether the fractionation of the whole erythrocyte population by graded osmotic hemolysis affected the stability of the $\mathrm{Fe}^{50}$ labeled hemoglobin. Accordingly, the total radioactivity was measured in the "hemoglobin solutions" prepared from the supernatant solution and from the sedimented cells of the various fractions for each of the eight subjects. The sum of the counts per minute in the supernatant solution and in the sedimented cells from each fraction, expressed as per cent of the total counts per minute in the "hemoglobin solution" prepared from the whole red cell population, revealed a mean value of plus or minus one standard deviation equal to 101.5 plus or minus 4.8 per cent.

\section{RESULTS}

In the initial two studies (Subjects W and PR), washed erythrocytes prepared between 5 and 20 days following $\mathrm{Fe}^{59}$ administration were added to solutions of varying sodium chloride concentrations so as to give graded hemolysis between 2 and 100 per cent. In these experiments the hemoglobin $\mathrm{Fe}^{59}$ specific activity was lowest in the supernatant samples of the least hemolyzed fractions.
5 DAYS AFTER Fe 59 ADMINISTRATION

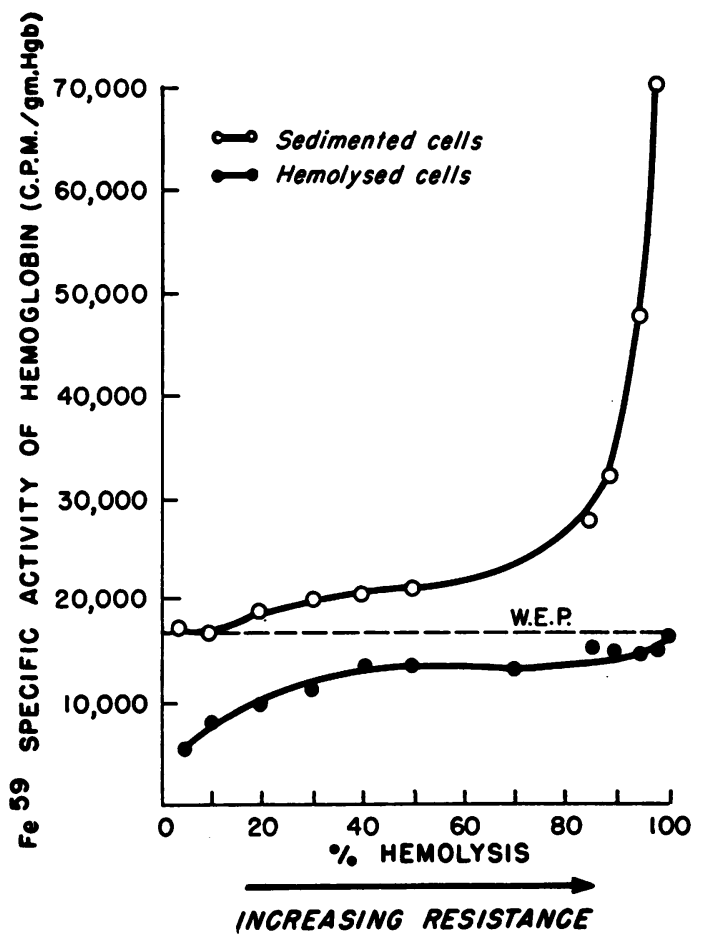

Fig. 1. Fes Specific Activity of the "Hemoglobin Solutions" Prepared from the Supernatant Solutions and Unlysed Cells Obtained by Graded Osmotic Hemolysis of Erythrocytes Five Days after Isotope Administration (SubJect PR)

The abbreviation W.E.P. is employed for the whole erythrocyte population.

These supernatant samples contain the hemoglobin of the least osmotically resistant cells. The highest specific activities were observed in the sedimented cells of the most hemolyzed fractions. These sedimented cells represent the most osmotically resistant erythrocytes. There were relatively small differences in specific activities of the "hemoglobin solutions" prepared from the supernatant and sedimented cells of the fractions between 20 and 80 per cent hemolysis. The data of one of these fractionations are presented in Figure 1. These findings suggested that an effective separation of the whole red cell population into fractions of relatively old and young mean cell age could be obtained by preparing the supernatant solutions of the less than 10 per cent levels of hemolysis and the unlysed cells of the more than 90 per cent levels of hemolysis. It appeared from these data that the 
greater the difference in osmotic fragility between the erythrocyte samples, the better the separation of young and old cells. However, in order to obtain adequate quantities of hemoglobin for specific activity measurements, it was necessary to employ the supernatant solution of the no less than 1.5 per cent level of hemolysis and the sedimented cells of the no more than 98.5 per cent level of hemolysis. Accordingly, in subsequent studies, determinations of hemoglobin specific activity were performed on the supernatant solutions of the 2 plus or minus $0.5,5$ plus or minus 1 , or 10 plus or minus 1 per cent levels of hemolysis and the sedimented cells of the 90 plus or minus 1,95 plus or minus 1 or 98 plus or minus 0.5 per cent levels of hemolysis. For each fractionation, these data were compared to the hemoglobin $\mathrm{Fe}^{59}$ specific activity of the whole erythrocyte population (Table I).

During the initial 30 to 35 days after $\mathrm{Fe}^{59}$ administration, it was observed that, relative to the whole erythrocyte population, the specific activities were higher in the more osmotically resistant erythrocyte fractions and lower in the less osmotically resistant erythrocyte fractions. Between approximately 35 and 80 days after isotope administration, the specific activities of both the more and less osmotically resistant erythrocyte fractions were less than that of the whole erythrocyte popu-

TABLE I

Specific activity of erythrocytes fractions of varying osmotic fragility related to the specific activity of the whole erythrocyte population at intervals after administration of $\mathrm{Fe}^{59}$

\begin{tabular}{|c|c|c|c|c|c|c|c|c|c|c|c|c|c|c|}
\hline \multirow[b]{4}{*}{ Days* } & \multicolumn{7}{|c|}{ Subject Z } & \multicolumn{7}{|c|}{ Subject W } \\
\hline & \multirow{3}{*}{$\begin{array}{l}\text { Fe"s.SA } \\
\text { W.E.P.t }\end{array}$} & \multicolumn{6}{|c|}{ Fraction of cells $\$ .8$} & \multirow[b]{3}{*}{ W.E.P. } & \multicolumn{6}{|c|}{ Fraction of cells } \\
\hline & & \multicolumn{3}{|c|}{ Most resistant } & \multicolumn{3}{|c|}{ Least resistant } & & \multicolumn{3}{|c|}{ Most resistant } & \multicolumn{3}{|c|}{ Least resistant } \\
\hline & & 2 & 5 & 10 & 10 & 5 & 2 & & 2 & 5 & 10 & 10 & 5 & 2 \\
\hline \multirow{8}{*}{$\begin{array}{r}5 \\
10 \\
15 \\
20 \\
25 \\
30 \\
35 \\
40 \\
50 \\
60 \\
70 \\
80 \\
90 \\
100 \\
110 \\
120\end{array}$} & $\begin{array}{r}88,000 \\
128,000\end{array}$ & $\begin{array}{l}5.70 \\
2.68\end{array}$ & 4.40 & 2.07 & $\begin{array}{l}0.17 \\
0.56\end{array}$ & 0.07 & 二 & 116,000 & 3.91 & - & - & 0.29 & - & - \\
\hline & 132,000 & 2.53 & $2 . \overline{02}$ & $\begin{array}{l}1.58 \\
1.68\end{array}$ & 0.57 & - & $\overline{0.22}$ & 138,000 & 2.87 & - & 2.01 & 0.40 & - & 0.17 \\
\hline & 138,000 & 1.21 & 1.19 & 1.30 & - & 0.45 & & & & & & & & \\
\hline & & & & & & & & 140,000 & 一 & 1.36 & 1.16 & - & - & 0.31 \\
\hline & 140,000 & 一 & 0.65 & 0.75 & - & 0.49 & 0.53 & 134,000 & - & 0.75 & 0.80 & 0.70 & - & - \\
\hline & 143,000 & 0.33 & 0.65 & 0.79 & 0.73 & 0.62 & 0.80 & 130,000 & 0.33 & 0.65 & 0.79 & 0.73 & - & 0.43 \\
\hline & 125,000 & 0.54 & 0.77 & - & 2.61 & 3.83 & 一 & 110,000 & - & 0.89 & 0.77 & 2.42 & - & 3.83 \\
\hline & & & & & & & & 88,000 & - & - & 1.04 & 2.32 & - & 2.71 \\
\hline \multirow[b]{4}{*}{ Days } & \multicolumn{7}{|c|}{ Subject PR } & \multicolumn{7}{|c|}{ Subject LA } \\
\hline & & \multicolumn{6}{|c|}{ Fraction of cells } & . & \multicolumn{6}{|c|}{ Fraction of cells } \\
\hline & & \multicolumn{3}{|c|}{ Most resistant } & \multicolumn{3}{|c|}{ Least resistant } & \multirow{2}{*}{$\begin{array}{l}\text { Few SA } \\
\text { W.E.P. }\end{array}$} & \multicolumn{3}{|c|}{ Most resistant } & \multicolumn{3}{|c|}{ Least resistant } \\
\hline & W.E.P. & 2 & 5 & 10 & 10 & 5 & 2 & & 2 & 5 & 10 & 10 & 5 & 2 \\
\hline \multirow{8}{*}{$\begin{array}{r}5 \\
10 \\
15 \\
20 \\
25 \\
30 \\
35 \\
40 \\
50 \\
60 \\
70 \\
80 \\
90 \\
100 \\
110 \\
120\end{array}$} & $\begin{array}{l}40,000 \\
80,000\end{array}$ & $\begin{array}{l}3.70 \\
3.50\end{array}$ & $\begin{array}{l}2.50 \\
1.90\end{array}$ & $\begin{array}{l}2.10 \\
2.20\end{array}$ & 0.50 & $\begin{array}{l}0.40 \\
0.30\end{array}$ & 二 & 56,000 & - & 2.64 & 2.30 & 0.20 & 0.15 & - \\
\hline & 88,000 & - & & 1.60 & 0.40 & & - & 59,000 & - & 1.49 & 1.29 & 0.47 & 0.53 & - \\
\hline & 90,000 & 1.20 & - & 2.00 & 0.45 & 0.30 & - & & & & & & & \\
\hline & 92,000 & 1.00 & - & 1.20 & 1.00 & 0.90 & 1.00 & 62,000 & - & 0.72 & 0.80 & - & 0.63 & 一 \\
\hline & 84,000 & - & 0.30 & 0.60 & 一 & 0.70 & 一 & & & & & & & \\
\hline & 89,000 & 0.65 & 0.30 & 0.70 & 0.85 & 0.40 & 0.70 & 60,000 & - & 0.42 & 0.79 & - & 0.99 & \\
\hline & 82,000 & - & - & 0.70 & 1.70 & 2.80 & - & & - & 0.42 & 0.19 & - & 0.99 & \\
\hline & 64,000 & - & - & 1.60 & - & - & - & 45,000 & - & - & 1.12 & 1.90 & 2.12 & - \\
\hline
\end{tabular}

* Days after $\mathrm{Fe}^{50}$ administration. average of the specific activities of the allquot of washed whole erythrocyte population and the water-lysed erythrocytes. These specific activities differed on the average 4.2 per cent plus or minus standard deviation of 2.7 per cent.

differed on the average 4.2 per cent plus or minus standard deviation of 2.7 per cent. and the 10 plus or minus 1,5 plus or minus 1 and 2 plus or minus 0.5 per cent least resistant to hypotonic hemolysis.

The values for the ratio represents: $\frac{\mathrm{Fe}^{60} \text { specific activity of the fraction of erythrocytes }}{\mathrm{Fe}^{50} \text { specific activity of the whole erythrocyte population }}$. Where a dash (-) appears, the sample was not obtained for an analysis. 
TABLE I-Continued

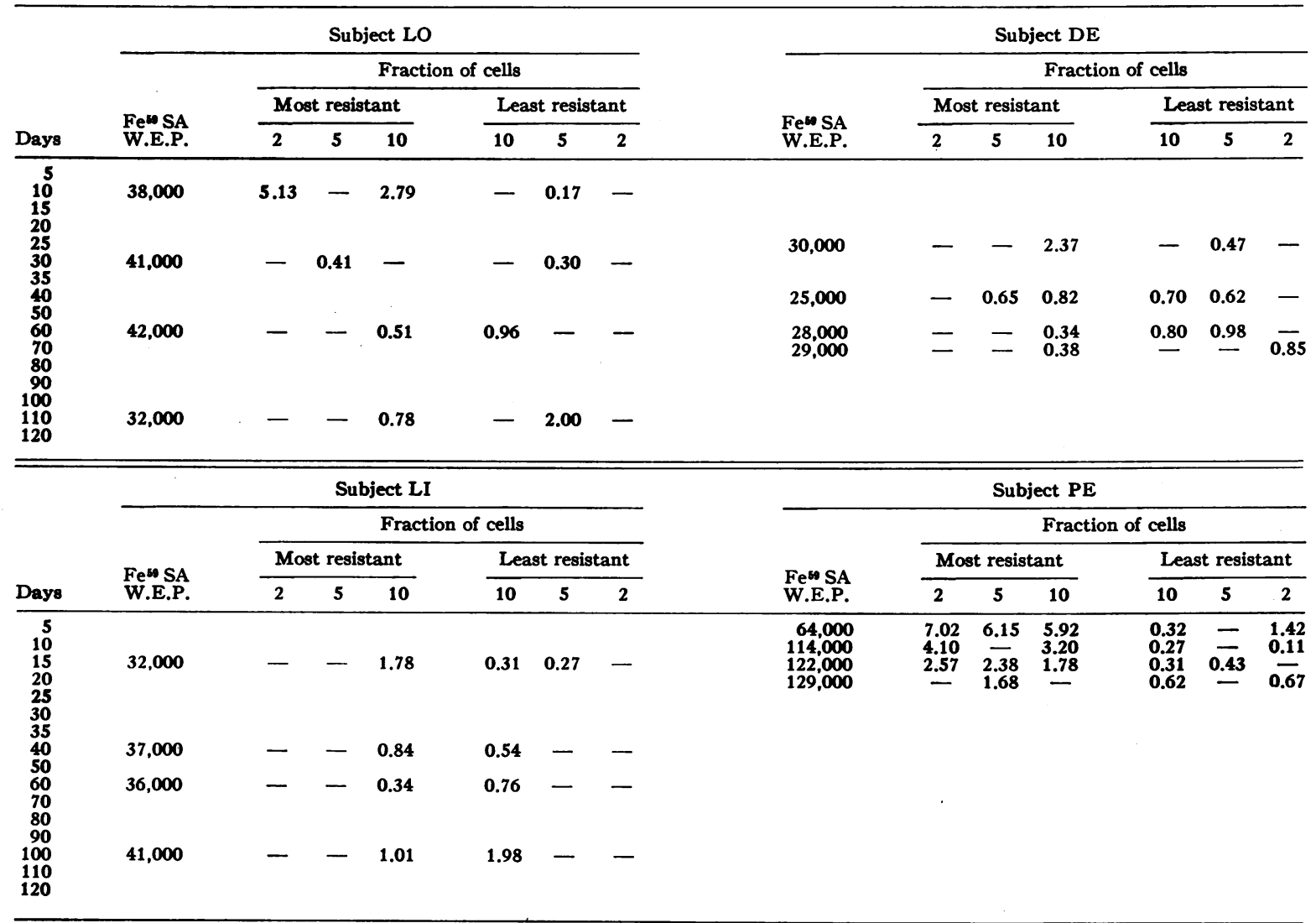

lation. In experiments performed at 90 days or longer following $\mathrm{Fe}^{59}$ administration, the specific activities of the less osmotically resistant red cells and, though to a smaller extent, the more osmotically resistant cells tended to exceed that of the whole erythrocyte population. The rise in specific activity of the more resistant (younger) erythrocyte fractions 90 days or more after isotope administration is presumably a result of the reutilization of $\mathrm{Fe}^{58}$. Previous investigators have shown that while intravenously administered $\mathrm{Fe}^{50}$ incorporation is limited to newly forming erythrocytes, isotope released from cells as they are destroyed is available for re-incorporation into immature red cells $(8,9,14)$.

\section{DISCUSSION}

The present data are consistent with the conclusions that young mature human erythrocytes are more resistant to hemolysis in hypotonic media than the average of the whole cell population, while old red cells are less resistant to osmotic hemolysis than the average of the total erythrocyte population. The method of graded osmotic hemolysis presented in this study provides a means of fractionation of the whole erythrocyte population in a manner whereby the more resistant cell fractions are progressively enriched with regard to young red cells and improverished with respect to old and middle-aged cells. The less osmotically resistant cell fractions are progressively enriched with regard to old erythrocytes and impoverished with respect to young and middle-aged cells. Among the eight subjects studied there was definite individual variation in the degree to which graded osmotic hemolysis achieved a separation of young and old red cells.

It must be emphasized that the differences in mean cell age among the fractions of erythrocytes of varying osmotic resistance are the result of a partial separation of young and old red cells. The assumption may be made that the relative 


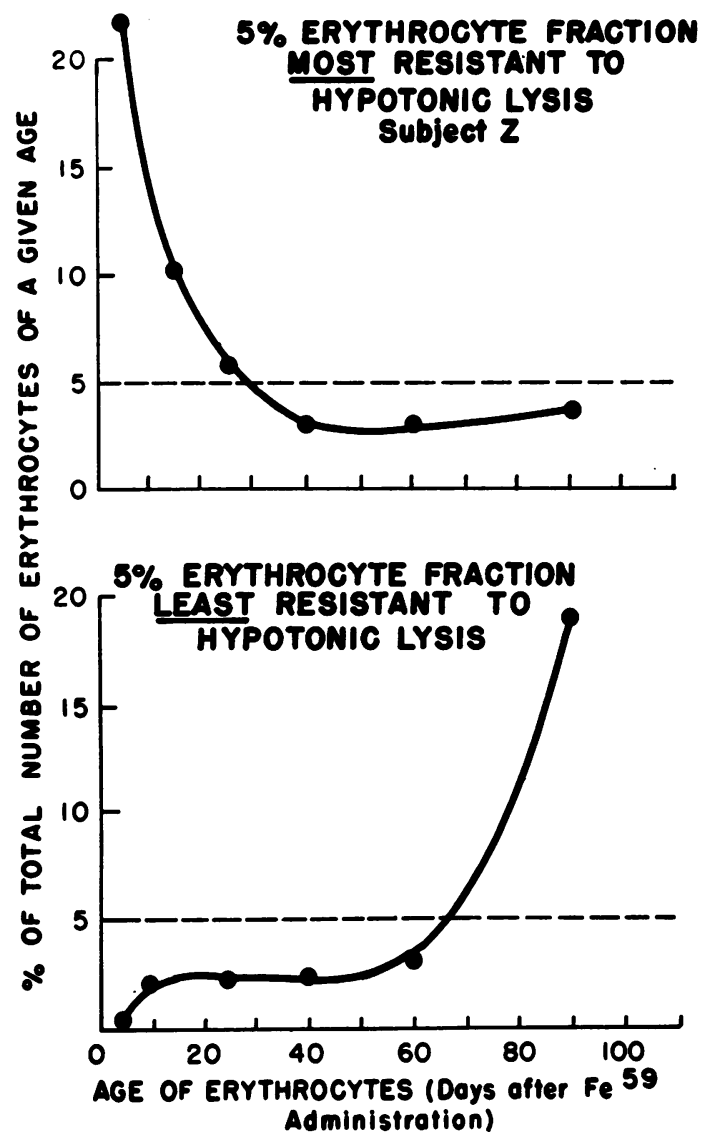

Fig. 2. The Distribution of Erythrocytes of Different Ages in the 5 Per Cent Most and Least Osmotically Resistant Red Cell Fractions of SubJECT Z

enrichment (or impoverishment) of a particular fraction with erythrocytes of a given age is equal to the ratio of hemoglobin specific activities of the fraction to that of the whole red cell population. The validity of this assumption is based on the observations $(8-11)$ that injected $\mathrm{Fe}^{59}$ will label only newly formed erythrocytes of a limited age. Such an assumption permits the estimation from the present data of the distribution of red cells of differing ages in a fraction of a given osmotic resistance. This estimation is obtained by multiplying the per cent of the total erythrocyte population in the given fraction by the ratio of the hemoglobin specific activities of the fraction to that of the whole erythrocyte population at the various time intervals following $\mathrm{Fe}^{59}$ administration (these ratios are presented in Table I). An example (Sub- ject $Z$ ) of the results of the calculation of the abundance of red cells of varying ages in the 5 per cent erythrocytes most and least resistant to hemolysis in hypotonic media is given in Figure 2. Thus, in this subject, the 5 per cent most osmotically resistant cell fraction contained 22.0 per cent of all erythrocytes five days old or younger but only 3.9 per cent of all erythrocytes about 90 days of age. On the other hand, in the 5 per cent least osmotically resistant cell fraction there were 19.1 per cent of all erythrocytes about 90 days of age but only 0.4 per cent of erythrocytes five days old or younger.

The present method of graded osmotic hemolysis provides sufficiently good separation of erythrocytes into fractions of differing mean cell age to permit evaluation of the effect of age on erythrocyte enzyme activity (15). Thus, the levels of glucose-6-phosphate dehydrogenase, 6-phosphogluconic dehydrogenase and phosphohexose isomerase were markedly higher in the young than old red cell fractions. Purine nucleoside phosphorylase and lactic acid dehydrogenase activities decreased relatively little with the in vivo aging of erythrocytes. Recently, Sterling, Greenfield and Price (6) reported that aldolase activity was higher in osmotically resistant rat erythrocytes than in the whole red cell population.

Employing a different technique for the fractionation of human erythrocytes by osmotic hemolysis, Simon and Topper (7) achieved a separation of young and old cells at $37^{\circ} \mathrm{C}$. and $22^{\circ} \mathrm{C}$. but not at $4^{\circ} \mathrm{C}$. In addition, these authors found that at these higher temperatures, the least osmotically resistant red cell fractions were enriched with young erythrocytes, though the major portion of young cells were in the most resistant fractions. This method differed from that employed in the present study in that a single aliquot of blood was serially subjected to hemolysis in hypotonic sodium chloride solutions. The present technique was primarily developed to separate erythrocytes of varying age under conditions which would permit subsequent biochemical studies. Since certain enzymes and metabolic intermediates are less stable at higher temperatures, a study has not been made of the effect of temperatures other than $0^{\circ} \mathrm{C}$. on the fractionation achieved by the present method. In the present study, with 
a single exception (Subject PE, 2 per cent least resistant fraction, five days following $\mathrm{Fe}^{59}$ administration, Table I), no evidence was found for the enrichment of the less osmotically resistant cell fractions with young erythrocytes. The present data, however, cannot exclude the possibility that there may be red cells younger than five days which are more fragile than older cells.

Several previous investigators (16-24) have employed methods of centrifugation or sedimentation to separate red cells into populations of different mean ages. These techniques are based on the fact that young erythrocytes are less dense than old cells. The methods of centrifugation and sedimentation can provide populations of cells enriched with young and with old erythrocytes in an unlysed state, while only young red cell fractions may be obtained unlysed following separation by the technique of osmotic hemolysis. However, in experiments not requiring intact red cells, e.g., studies of enzyme activity and cell free systems, graded osmotic hemolysis, compared to centrifugation, provided erythrocyte fractions with apparently greater differences in mean cell ages $(15,25)$.

\section{SUM M ARY}

A method of graded osmotic hemolysis has been described which separates the whole erythrocyte population into fractions of differing mean cell age. This method has been validated by employing $\mathrm{Fe}^{59}$ labeling in vivo to date the age of red cells. Young mature human erythrocytes were found to be more resistant to hemolysis in hypotonic media than old cells.

\section{ACKNOWLEDGMENTS}

The authors are indebted to Doctors George Hyman and Robert De Bellis for their assistance during the course of this study. We are indebted to Miss Maureen Donohue and Mr. Anthony Dente for their technical assistance.

\section{REFERENCES}

1. Marks, P. A. A relationship between human erythrocyte aging in vivo and the activities of glucose-6phosphate and 6-phosphogluconic dehydrogenase (abstract). J. clin. Invest. 1957, 36, 913.

2. Cruz, W. O., Hahn, P. F., Bale, W. F., and Balfour, W. M. The effect of age on the susceptibility of the erythrocyte to hypotonic salt solutions. Radioactive iron as a means of tagging the red blood cell. Amer. J. med. Sci. 1941, 202, 157.

3. Stewart, W. B., Stewart, J. M., Izzo, M. J., and Young, L. E. Age as affecting the osmotic and mechanical fragility of dog erythrocytes tagged with radioactive iron. J. exp. Med. 1950, 91, 147.

4. Chalfin, D. Differences between young and mature rabbit erythrocytes. J. cell. comp. Physiol. 1956, 47, 215.

5. Jaffé, E. R., Vanderhoff, G. A., Lowy, B. A., and London, I. M. The effect of nucleosides on osmotic resistance of mammalian erythrocytes in relation to the age of the cells (abstract). J. clin. Invest. 1957, 36, 903.

6. Sterling, W. R., Greenfield, R. E., and Price, V. E. Erythrocytes of tumor-bearing animals (abstract). Fed. Proc. 1958, 17, 316.

7. Simon, E. R., and Topper, Y. J. Fractionation of human erythrocytes on the basis of their age. Nature (Lond.) 1957, 180, 1211.

8. Walsh, R. J., Thomas, E. D., Chow, S. K., Fluharty, R. G., and Finch, C. A. Iron metabolism. Heme synthesis in vitro by immature erythrocytes. Science 1949, 110, 396.

9. Lajtha, L. G., and Suit, H. D. Uptake of radioactive iron $\left({ }^{50} \mathrm{Fe}\right)$ by nucleated red cells in vitro. Brit. J. Haemat. 1955, 1, 55.

10. Hahn, P. F., Bale, W. F., Ross, J. F., Hettig, R. A., and Whipple, G. H. Radio-iron in plasma does not exchange with hemoglobin iron in red cells. Science 1940, 92, 131.

11. Gibson, J. G., 2nd, Weiss, S., Evans, R. D., Peacock, W. C., Irvine, J. W., Jr., Good, W. M., and Kip, A. F. The measurement of the circulating red cell volume by means of two radioactive isotopes of iron. J. clin. Invest. 1946, 25, 616.

12. Drabkin, D. L. Spectrophotometric studies. XIV. The crystallographic and optical properties of the hemoglobin of man in comparison with those of other species. J. biol. Chem. 1946, 164, 703.

13. Ranney, H. M., and Kono, P. Iron-59 incorporation into major and minor hemoglobin components. Submitted for publication.

14. Eadie, G. S., and Brown, I. W., Jr. Red blood cell survival studies. Blood 1953, 8, 1110.

15. Marks, P. A., Johnson, A. B., and Hirschberg, E. Effect of age on the enzyme activity of human erythrocytes. Proc. nat. Acad. Sci. (Wash.) 1958, 44, 529.

16. Watson, C. J., and Clarke, W. O. The occurrence of protoporphyrin in the reticulocytes. Proc. Soc. exp. Biol. (N. Y.) 1937, 36, 65.

17. Stephans, J. G. Surface and fragility differences between mature and immature red cells. J. Physiol. 1940, 99, 30.

18. Ferrebee, J. W., Gibson, J. G., and Peacock, W. C. Studies on malarial parasites. IV. Some obser- 
vations regarding the age of the erythrocyte invaded by plasmodium vivax. J. infect. Dis. 1946, 78, 180.

19. Pritchard, J. A. Erythrocyte age and cholinesterase activity. Amer. J. Physiol. 1949, 158, 72.

20. Sabine, J. C. The cholinesterase of erythrocytes in anemias. Blood 1951, 6, 151.

21. Finch, C. A., Wolff, J. A., Rath, C. E., and Fluharty, R. G. Iron metabolism. Erythrocyte iron turnover. J. Lab. clin. Med. 1949, 34, 1480.

22. Dreyfus, J. C., Schapira, G., and Kruh, J. Fractionnement des Hématies selon leur âge. Centrifuga- tion d'hématies marquées par le fer radioactif. C. R. Soc. Biol. (Paris) 1950, 144, 792.

23. Borun, E. R., Figueroa, W. G., and Perry, S. M. The distribution of $\mathrm{Fe}^{\infty}$ tagged human erythrocytes in centrifuged specimens as a function of cell age. J. clin. Invest. 1957, 36, 676.

24. Allison, A. C., and Burn, G. P. Enzyme activity as a function of age in the human erythrocyte. Brit. J. Haemat. 1955, 1, 291.

25. Marks, P. A., Johnson, A. B., Hirschberg, E., and Banks, J. Studies on the mechanism of red cell aging. Ann. N. Y. Acad. Sci. In press. 